\section{Questión}

Periodismo / Comunicación ISSN 1669-6581
- Av. $44 \mathrm{~N}^{\circ} 676,1^{\circ}$ piso

CP 1900 - La Plata - Argentina

(i) www.perio.unlp.edu.ar/question

Escuchar la radio para romper el aislamiento

Agustín Espada

DOI: https://doi.org/10.24215/16696581e300

\title{
Escuchar la radio para romper el aislamiento
}

\section{Listen to the radio to break the insulation}

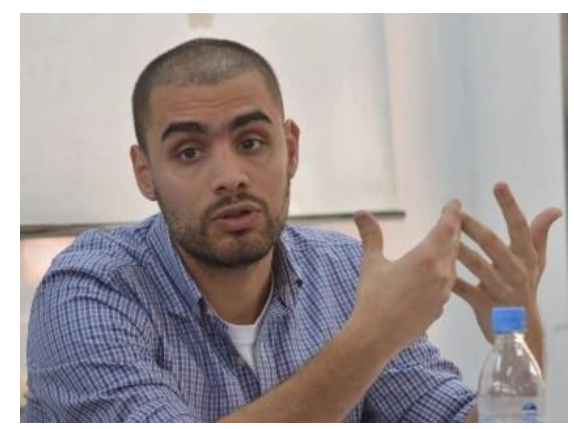

"Las ondas de la radio van por el aire, no se caen con internet ni con el cable. Llevan nuestras voces, la magia del gordo (Mauro Eyo), sus audios, la música... Pero la llevan distinto a la música. Porque si antes, en tu rutina frenética, vos querías aislarte de ese mundo hostil de alrededor con una lista de Spotify hecha a medida y muchas veces decías "me cansé de la realidad, me aíslo", ahora que estás aislado por obligación, la radio en vivo te hace parte de 
una comunidad de nuevo. Nosotros somos compañía, es un frase trillada pero que se resignifica en tiempos de cuarentena".

Alejandro Bercovich, Radio Con Vos, jueves 2 de abril de 2020. Día 14 de aislamiento social obligatorio en Argentina.

En tiempos de encierro y cuarentena, la radio tiene un gran espacio entre los consumos culturales. Sin poder salir de casa, con la computadora, el televisor y el celular a mano todo el día, la radio sigue encendida. ¿Por qué? ¿Qué es lo que hace que en tiempos de consumo de información y entretenimiento en hogares, de dónde no se puede (ni debe) salir, una voz que nos habla a través de un parlante que toma la señal del aire o de un reproductor de streaming sea atractivo e interesante?

Primero los datos. Las principales corporaciones de radio en Reino Unido indican que sus oyentes en internet crecieron entre un $15 \%$ y un $18 \%$. Ivoox, plataforma de radio en internet española, registra una caída en la escucha de podcasts pero un aumento del $20 \%$ en las conexiones a los streamings de las radios, en especial las informativas. Deezer, la plataforma musical, muestra lo mismo: la radio le gana al podcast y la música en tiempos de coronavirus. En Holanda, el tiempo de escucha de radio y la cantidad de oyentes marcan aumentos del $11 \%$ y el 7\%, respectivamente. En Argentina, las radios tienen picos máximos históricos de conexión a sus reproductores. Kantar muestra que un $24 \%$ de los argentinos escucha más radio en internet.

\section{Otra vez: ¿por qué?}

La radio en tiempos de internet y de plataformas sociales es algo difícil de definir. O, por lo menos, algo desafiante, un objeto que se mueve y transforma año tras año. Sin embargo, se puede arriesgar que la radio es la oferta y la escucha de unos contenidos que combinan el vivo con lo grabado, el directo con la demanda (diferido), con un lenguaje específico (compuesto por voces, silencios, música y efectos sonoros), que utiliza una amplia gama de dispositivos y tecnologías de transmisión y que se sirve de otras herramientas y textos para complementarse. Pero el sonido siempre es el principal objeto comunicador.

Por fuera de esta definición teórica, de manual, la radio es compañía. Es rutina, un medio amigo y cercano. Es fuente de información, entretenimiento y distracción en momentos de 
trabajo, viajes monótonos por la ciudad -esos que casi no suceden ahora-, esfuerzos de entrenamiento y sacrificios como sacar al perro a las siete de la mañana.

Existen algunos conceptos claves para entender por qué prendemos la radio, a través de cualquier plataforma, en tiempos de encierro: intimidad, confianza, cercanía, co-presencia y comunidad imaginada. Todas esas características hacen que se resignifique su escucha en medio de la pandemia.

Escuchar la radio es una paradoja: al tiempo que la mayoría de las veces que nos conectamos al medio lo hacemos de forma solitaria y personal, las voces que salen de los auriculares 0 parlantes nos conectan con una gran comunidad que nos acompaña en nuestro quehacer. La escucha íntima refuerza la confianza en quien nos habla del otro que, por la forma de consumo y de construcción discursiva, parece que nos hablara a nosotros exclusivamente. Mejor dicho, a mí, que escucho.

A su vez, algo que podría verse como una debilidad en la radio, su falta de imágenes, también es su fortaleza. El trabajo que los oyentes realizamos con nuestra imaginación para reconstruir los relatos escuchados implica un compromiso e involucramiento mayor con el contenido. $Y$ un sentido de identificación también, como dice David Hendy. La radio crea (no en el sentido de inventar) un mundo que los y las oyentes somos invitados a habitar: se puede participar con comentarios por distintas vías pero también lo habitamos a sola escucha.

Hugh Chignell, uno de los teóricos más importantes de la radio, dice: "existen varios factores que colaboran con la sensación de intimidad. El primero es el hecho de que la mayor parte de la escucha de radio es un acto individual; el segundo es que algunas emisoras y conductores invitan a sus oyentes a trabajar con su imaginación para habitar un mundo interior; en tercer lugar, el discurso de la radio es habitualmente directo y en primera persona; y, por último, los conductores de los programas suelen ser personas comunes (no grandes estrellas) y amigables".

Una de las principales fortalezas de la radio en estos momentos de encierro y aislamiento social es que una de las bases de funcionamiento como institución social y cultural es su capacidad para generar "co-presencia". Es esa sensación que tenemos cuando encendemos la radio de que hay otros que hacen lo mismo, que escuchan cuando nosotros escuchamos. Y es una experiencia bien diferente a escuchar el mismo artista, el mismo podcast o mirar la misma serie en televisión. 
Primero porque la falta de imágenes, la explotación de la imaginación de los oyentes y la "secundariedad" de la radio que permite escucharla mientras realizamos otras actividades hacen que se genere una identificación mayor entre los oyentes y los conductores. $Y$ "escuchar" algo es una actividad centrípeta, en términos de Susan Douglas. Nos "mete" en un mundo, nos acerca. "Mirar" algo es una actividad centrífuga, te separa del mundo mostrado. Y esto acuerda con la perspectiva de José Luis Fernández, quien cuenta que el sonido se mueve "dentro" de nuestra cabeza mientras las imágenes están allá afuera. La capacidad de identificación y socialización del sonido cuando se conjuga con la simultaneidad de la emisión y la recepción es altísima.

En segundo lugar: la radio está en vivo. Esto quiere decir que no solo se comparte el consumo de cierto medio, programa o conductor: se hace en el mismo momento del día. En diferentes lugares, miles de espacios, pero un solo tiempo. En eso consiste la co-presencia en la escucha. En una relación muy fuerte de identificación, confianza y cercanía con el medio que se da en una situación de consumo casi siempre individual pero que nos conecta con otras personas. Que hoy, como todos, está encerrada en otro punto del mundo pero escucha lo mismo que yo, en el mismo momento.

Y en la "secundariedad" de la radio como medio de comunicación -la podemos escuchar mientras hacemos otras cosas- reside otra de sus fortalezas en este momento: marca los momentos del día. El consumo de un programa, columna o escuchar cierta cortina o marca sonora nos lleva, en asociación directa, con nuestra rutina, el orden establecido de nuestras cosas.

Esta relación fuerte de cercanía, confianza y co-presencia hace a uno de los productos de la radio: la construcción de comunidades imaginadas. Una de las funciones originarias de la radio, surgida en un mundo que destruía sociedades en medio de Guerras Mundiales y aluviones migratorios, fue reconstruir los lazos de identificación social y de colectivos culturales perdidos por el contexto bélico y económico. Hoy, 100 años después, la radio nos reconstruye lo que sucede allá fuera, donde no podemos (ni debemos) ir, con un sentido de pertenencia a un colectivo que comparte no solo la escucha de un programa o emisora sino también valores e identidades culturales (como puede ser el gusto por cierto estilo musical, tipo de humor o línea editorial).

El mundo se detiene. Las calles se silencian. Y el silencio, muchas veces, es el mejor escenario 
para la escucha. En los hogares las radios se encienden. En un contexto previo donde las pantallas, lo audiovisual y el consumo a la carta (on demand) dominaban el acceso a la información y el entretenimiento, el aislamiento social nos obliga a conectarnos con "los otros y las otras" a través de los medios masivos (entre otras tecnologías). La música, las noticias o las voces que escuchamos en la radio quizás no sean las que elegiríamos o preferiríamos exactamente en "ese" momento pero son las que nos hacen sentir que estamos todos desde nuestras casas conectados y existentes en el mismo momento. Vivos a través del éter. 